\title{
COMBINED NEWTON'S THIRD-ORDER CONVERGENCE METHOD FOR MINIMIZE ONE VARIABLE FUNCTIONS
}

\author{
Kodnyanko V. A. - Dr. Sc., Professor, Polytechnic Institute, Siberian Federal University, Krasnoyarsk, Russia. \\ Grigorieva O. A. - PhD, Associate Professor, Polytechnic Institute, Siberian Federal University, Krasnoyarsk,
} Russia.

Strok L. V. - Postgraduate student, Polytechnic Institute, Siberian Federal University, Krasnoyarsk, Russia.

\section{ABSTRACT}

Contex. The article deals with the actual problem of numerical optimization of slowly computed unimodal functions of one variable. The analysis of existing methods of minimization of the first and second orders of convergence, which showed that these methods can be used to quickly solve these problems for functions, the values of which can be obtained without difficulty. For slowly computed functions, these methods give slow algorithms; therefore, the problem of developing fast methods for minimizing such functions is urgent.

Objective. Development of a combined third-order Newtonian method of convergence to minimize predominantly slowly computed unimodal functions, as well as the development of a database, including smooth, monotonic and partially constant functions, to test the method and compare its effectiveness with other known methods.

Method. A technique and an algorithm for solving the problem of fast minimization of a unimodal function of one variable by a combined numerical Newtonian method of the third order of convergence presented. The method is capable of recognizing strictly unimodal, monotonic and constant functions, as well as functions with partial or complete sections of a flat minimum.

Results. The results of comparison of the proposed method with other methods, including the fast Brent method, presented. 6954 problems were solved using the combined Newtonian method, while the method turned out to be faster than other methods in $95.5 \%$ of problems, Brent's method worked faster in only $4.5 \%$ of problems. In general, the analysis of the calculation results showed that the combined method worked 1.64 times faster than the Brent method.

Conclusions. A combined third-order Newtonian method of convergence proposed for minimizing predominantly slowly computed unimodal functions of one variable. A database of problems developed, including smooth, monotone and partially constant functions, to test the method and compare its effectiveness with other known methods. It is shown that the proposed method, in comparison with other methods, including the fast Brent method, has a higher performance.

KEYWORDS: unimodal function, Brent method, combined Newton minimization method, method speed.

\author{
ABBREVIATIONS \\ $\mathrm{BM}$ is a Brent method; \\ DS is a dichotomous search; \\ GSS is a golden section search; \\ EDS is an economical dichotomous search; \\ MF is a minimizing function; \\ $\mathrm{N} 3 \mathrm{o}$ is a Newton's method of the third order of \\ convergence.
}

\section{NOMENCLATURE}

$f(x)$ is an unimodal function;

$G=[a, b]$ is an uncertainty segment;

$\varepsilon$ is a calculation accuracy;

$E=p^{1 / \sigma}$ is an efficiency index;

$p$ is an order of convergence of the method;

$\sigma$ is a number of calculations;

$\delta$ is a number close to machine zero;

$x_{i}$ is a current point of the iterative process, $a_{i}, b_{i}$ are the current boundaries of the uncertainty segment at iteration with number $i, \delta$ is a number close to machine zero;

$h_{i}=\alpha\left(b_{i}-a_{i}\right)$ is a minimum gap restricting the excessive convergence between a new point and the boundaries of the uncertainty segment to hamper the slowdown of the computational process;

$\alpha<0.5$ is a coefficient; $k_{g}$ is a number of calls of the GSS to the MF necessary to solve the problem.

\section{INTRODUCTION}

Numerical optimization of one-variable functions is one of the most common computational problems [1-4]. In practice, minimization of unimodal functions [5-8] that may have an extremum in a point or segment of the uncertainty segment where the function is constant is one of the most frequently used procedures. Most often, it is for unimodal functions that numerical minimization methods are developed.

First- and second-order convergence methods applied to solve these problems quickly and without difficulties [9-11]. The difference in their use becomes only visible when the computation time required to calculate the minimizing function becomes many times greater than the execution time of computational operations that implement the optimization method. Although the method itself operates fast, it is the slow MF computations that eventually slow down the solution algorithm.

\section{PROBLEM STATEMENT}

The class of slow-computed MF's is very broad. Typical examples are functions obtained by solving computational problems for theoretical models of various technical objects, where mathematical modeling involves 
one or more multidimensional differential equations, often nonlinear. The numerical methods used to solve these problems usually require a large amount and high accuracy of calculations, thus consuming a significant amount of computer time to calculate a single MF value.

The proposed method is designed to find the abscissa $x$ of the minimum of the unimodal one-variable function $f(x)$ on the segment $G=[a, b]$ up to $\varepsilon$.

During the search for a solution, at each iteration, a part of the current uncertainty segment $G$ is cut off until the condition

$$
\left|b_{i}-a_{i}\right| \leq \varepsilon\left|x_{i}\right|+\delta
$$

The value of the parameter $\delta$ was chosen from the following considerations. If the arithmetic type of machine variables equals to $2 m$ significant decimal digits, then we can put $\delta=10^{-m}$, which allows you to confidently operate with small numbers, without risking to affect the result of rounding errors when performing arithmetic calculations [16].

\section{REVIEW OF THE LITERATURE}

Even for fast-computed functions, when a large number of calls to the algorithm is required to achieve the result, it also becomes slow. Such problems include, for example, multi-parameter optimization of dynamic systems by performance criteria, where one-dimensional optimization is used $[12,13]$.

For algorithms with slow-computed functions and intrinsically slow algorithms, a significant efficiency factor is the number of $k$ calls to the MF, which determines the speed of the algorithm and the corresponding method. Obviously, the less calls are required to the $\mathrm{MF}$, the higher the speed of the algorithm and method.

For local minimization of one-variable functions, numerical first-order convergence methods are usually used. The preferred ones are the dichotomy search [2, 5], the golden section search [14] and the economical dichotomy search, the latter being superior in speed [15]. More often, second-order convergence methods are used, among which the leadership belongs to the Brent combined parabolic method [16]. The first-order methods are offer guaranteed reliability, however, in comparison with BM, with the same accuracy, they require a significantly larger number of $k$ calls to the MF.

Along with BM, the Newton's analytic method [2, 9, 10], which has a second order of convergence, is used, which is highly efficient, especially when minimizing smooth functions. However, in terms of speed, when applied to slow-computed functions, a similar method based on numerical determination of the first derivative is noticeably inferior not only to BM, but even to first-order convergence methods. On this basis, it believed that for MF's requiring numerical differentiation, the Newton

(C) Kodnyanko V. A., Grigorieva O. A., Strok L. V., 2021 DOI 10.15588/1607-3274-2021-2-5 method does not have any competitive advantage over the above-mentioned methods.

For optimization, we can try to apply new interpolation methods of third-order convergence, which give a quick solution to nonlinear equations [17]. When applied to smooth functions for the first derivative of the MF, these methods can yield a quick solution to the problem under consideration. The study of this opportunity is one of the objectives of this article.

In mass computing processes, monotonous, constant, or partially constant functions are often minimized. The Brent method applied to such functions does not give a gain in speed as compared to first-order methods, while monotonicity or constancy of the MF can be determined several times faster than the BM solution or one of the first-order methods. To study the opportunity to accelerate the minimization procedure for this class of functions is one of the goals of this study.

The following sections of the article discuss the method to attain the two above-mentioned objectives.

\section{MATERIALS AND METHODS}

The method includes two procedures to find the minimum MF

- Newton's method of third order convergence,

- method to identify its monotony and constancy segment.

The method is based on the provisions of [17], which outlines the idea of solving a nonlinear equation for smooth functions using the two-point iterative Weerakoon-Fernando method

$$
\begin{aligned}
& x_{n+1}=x_{n}-\frac{2 f\left(x_{n}\right)}{f^{\prime}\left(x_{n}\right)+f^{\prime}\left(x_{n}^{*}\right)}, \\
& x_{n}^{*}=x_{n}-\frac{f\left(x_{n}\right)}{f^{\prime}\left(x_{n}\right)} .
\end{aligned}
$$

In relation to the considered problem, one should search for the zero of the first derivative of the MF in which its minimum is achieved, therefore, to use the method (2), it is necessary to replace the MF in it with its first derivative, and the latter with the second derivative of the MF.

Method (2) has a third order of convergence with the efficiency index $\sqrt[3]{3} \approx 1.44$ [17]. It works faster than the Newton method since its efficiency index $\sqrt{2} \approx 1.41$ is less (by the efficiency index we mean the quantity $\left.E=p^{1 / \sigma}\right)$.

In accordance with the proposed method, at each iteration, the MF is calculated only once; therefore, for $\sigma=1$, the efficiency index (3) for polynomial approximation will be $E=3$ against the Newton method for which $E=2$.

In the process of calculations, a sequence of points $P(i)=\left(x_{0}, y_{0}\right),\left(x_{1}, y_{1}\right), \ldots,\left(x_{i}, y_{i}\right)$ is formed. The necessary derivatives of the MF will be found by polynomial 
approximation of the MF with respect to the last $n+1$ points of the sequence $P$. Discarding the previous points, we obtain the sequence $P(n)$.

Imagine the MF polynomial

$$
\begin{aligned}
& y(x)=\sum_{i=0}^{n} e_{i} L_{i}(x)=T_{n}(x), L_{0}(x)=1 ; \\
& L_{i+1}(x)=L_{i}(x)\left(x-x_{i}\right) ; i=0,1, \ldots, n-1
\end{aligned}
$$

and find the unknown coefficients

$$
e_{0}=y_{0}, e_{1}=\frac{y_{1}-y_{0}}{x_{1}-x_{0}}, \ldots, e_{n}=\frac{y_{n}-T_{n-1}\left(x_{n}\right)}{L_{n}\left(x_{n}\right)} \text {. }
$$

The formulas to calculate the derivatives of the function $y(x)$ are obtained using recurrence formulas similar to the Aitken scheme [18-20]

$$
\begin{aligned}
& y^{\prime}(x)=\sum_{i=0}^{n} e_{i} L_{i}^{\prime}(x), L_{0}^{\prime}(x)=0, \\
& L_{i+1}^{\prime}(x)=L_{i}^{\prime}(x)\left(x-x_{i}\right)+L_{i}(x), \\
& i=0,1, \ldots, n-1, \\
& y^{\prime \prime}(x)=\sum_{i=0}^{n} e_{i} L_{i}^{\prime \prime}(x), L_{0}^{\prime \prime}(x)=0, \\
& L_{i+1}^{\prime \prime}(x)=L_{i}^{\prime \prime}(x)\left(x-x_{i}\right)+2 L_{i}^{\prime}(x), \\
& i=0,1, \ldots, n-1 .
\end{aligned}
$$

Now method (6) takes the form

$$
\begin{aligned}
& x_{n+1}=x_{n}-\frac{2 y^{\prime}\left(x_{n}\right)}{y^{\prime \prime}\left(x_{n}\right)+y^{\prime \prime}\left(x_{n}^{*}\right)}, \\
& x_{n}^{*}=x_{n}-\frac{y^{\prime}\left(x_{n}\right)}{y^{\prime \prime}\left(x_{n}\right)} .
\end{aligned}
$$

The above considerations regarding the effectiveness of the methods correspond to the exact MF and its derivatives, however, in our case, the application of formulas (2)-(7) gives approximate dependences, therefore, the effectiveness of such a process requires a further study.

The solution finding process begins with determination of the initial segment of uncertainty with the boundaries $a_{0}=a, b_{0}=b$ and two initial points

$$
\begin{aligned}
& x_{0}=\frac{a_{0}(1+\varepsilon)+b_{0}(1-\varepsilon)}{2}, y_{0}=f\left(x_{0}\right), \\
& x_{1}=\frac{a_{0}(1-\varepsilon)+b_{0}(1+\varepsilon)}{2}, y_{1}=f\left(x_{1}\right) .
\end{aligned}
$$

If $y_{0}=y_{1}$, then the solution is found in $k=2 \mathrm{MF}$ calculations.

Otherwise, in accordance with the dichotomy method, a new segment of uncertainty $\left[a_{1}, b_{1}\right]$ is built by removing from segment $\left[a_{0}, b_{0}\right]$ segment $\left[a_{0}, x_{0}\right]$ or segment $\left[x_{1}, b_{0}\right]$ and the third point is determined

$$
x_{2}=\frac{a_{1}+b_{1}}{2}, y_{2}=f\left(x_{2}\right) .
$$

Next, a parabola built at three points

$$
y(x)=c_{0}+c_{1}\left(x-x_{0}\right)+c_{2}\left(x-x_{0}\right)\left(x-x_{1}\right),
$$

where

$$
c_{0}=y_{0}, c_{1}=\frac{y_{1}-y_{0}}{x_{1}-x_{0}}, c_{2}=\frac{y_{2}-y_{0}-c_{1}\left(x_{2}-x_{0}\right)}{\left(x_{2}-x_{0}\right)\left(x_{1}-x_{0}\right)} .
$$

For $c_{2}>0$, the parabola has a minimum at the point

$$
x_{3}=\frac{1}{2}\left(x_{0}+x_{1}-\frac{c_{1}}{c_{2}}\right) \text {. }
$$

If $a_{1}<x_{3}<b_{1}$, then the point is considered conditionally suitable, since verification of $x 3$ is required to meet the condition

$$
a_{i}+h_{i}<x<b_{i}-h_{i}
$$

If and (5) is satisfied, then the abscissa of the new point is obtained and now we can calculate its ordinate $y_{3}=f\left(x_{3}\right)$.

In cases when parabolic approximation does not yield a new point, it is determined by the half division method similarly to (8).

Then, the left or right segment of the uncertainty segment is again discarded, thereby giving its reduced analogue $\left[a_{2}, b_{2}\right]$.

Subsequent points are determined similarly, that is, using a parabolic approximation. The only difference is: if the point is suitable, then it is only the initial approximation for the Newtonian process, which is represented by formulas (4)-(7). In cases where parabolic approximation does not yield a result, the last point of the sequence $P$ is taken for the initial approximation for method (4)-(7).

If in this case the found abscissa $x$ falls into the current segment of uncertainty $G_{i}=\left[a_{i}, b_{i}\right]$, but does not satisfy condition (10), then it is corrected by the formula

$$
x=\left\{\begin{array}{l}
a_{i}+h, x<a_{i}+h \\
b_{i}-h, x>b_{i}-h
\end{array}\right.
$$

If for $k>3$ at the current iteration neither the parabolic method nor the method (4)-(7) gives a result, then the new point is determined by the half division method. The process is repeated until the convergence condition (1) is satisfied.

While searching for the abscissa of the minimum, we also monitor the monotonicity and presence of constancy segment of the MF.

To monitor monotonicity, upon completion of the current iteration, sequence $P$ is sorted by argument. If, after such sorting, the corresponding sequence of MF 
values turns out to be monotonic, then starting from a certain iteration, the monotonicity of the MF is monitored.

It is known that the monotonicity of a unimodal function is detected in $4 \mathrm{MF}$ calculations [8]. However, with a small number of points of the sequence $P$, monotonicity monitoring can slow down the optimization process, in cases where the MF is not monotonic.

Therefore, this monitoring is only advisable when a true monotonicity of the function under minimization is highly probable.

Monotonicity monitoring is based on the number of $k$ calculations of the MF necessary to achieve the result.

If the sorted sequence $P$ gives a monotonic sequence of ordinates, then two additional calculations of the MF at one of the ends of the segment can quickly give a solution to the problem.

So if the sequence turns out to be increasing, then it suffices to calculate at the points $x=a$ and $x=a+\varepsilon$. If, by adding the ordinates of these points to the above mentioned sequence, the monotonic sequence is obtained again, then the solution is $x=a$.

A descending sequence is identified similarly, point $x=b$ being the solution to the problem.

The procedure to identify constant functions and presence of individual sections of constant MF allows to accelerate the MF optimization. The procedure is very simple and obvious: if the sorted sequence $P$ contains three points with the same ordinates, then the abscissa of any of them is a solution to the problem. This procedure does not require calculation of new MF values, however, for a number of functions it can significantly reduce the number and time of calculations.

\section{EXPERIMENTS}

To verify the method and other research goals, a problem base was built, its scope is determined by the product of the number of MF's used and the corresponding variants of uncertainty segments.

In numerical experiments, were used 26 extreme (the minimum of which is inside the uncertainty segments), two monotonic (increasing and decreasing), one constant and one partially constant functions.

Variants of the uncertainty segments for these MF's were found based on the following considerations. Each function was associated with a sufficiently wide segment $G=[a, b]$ and using the GSS, which was used as the control method, the abscissa $x_{m}$ was determined by solving the problem accurate to machine zero. Then we randomly found two points $c, d$ on the segment $[a, b]$, so that $d-c>\tau(b-a)$. This allowed us to obtain the uncertainty segments $[c, d]$ to solve the set of problems for a single function.

In the calculations, parameter $\tau$ was set from the range $0.25 \leq \tau \leq 1$, which made it possible to vary the length of the experimental segments for a certain function from a quarter to the full length of the segment $G$. The functions on the segments $[c, d]$ could be either monotonic, partially constant, or extreme.

(C) Kodnyanko V. A., Grigorieva O. A., Strok L. V., 2021

DOI 10.15588/1607-3274-2021-2-5
When conducting a computational experiment, the solution of $x$ problems was found accurate to $\varepsilon=10^{-6}$ for arithmetic quantities supporting 19-20 significant digits. In the calculations, $\alpha=0.12499$ was assumed.

The calculation results were compared with the indicators DS, EDS, GSS and BM.

The Brent method is programmed according to the original procedure [16], EDS is encoded based on the algorithm described in [15], DS and GSS are not difficult to encode.

\section{RESULTS}

To study the efficiency of the Newtonian third-order convergence procedure, only those segments $[c, d]$ and those functions that gave extremal problems for which the abscissa of the minimum of the MF fell inside these segments were selected.

A complete set of mass calculations was performed for all 30 functions for $\tau=0.33$. In total, this amounted to 7.530 problems. Of these, 2.566 were identified as problems with monotonous functions. Using the combined Newtonian method, 7.215 were solved faster $(95.8 \%)$, the Brent method was superior for only $4.2 \%$ of the problems. By the Brent method, the problems were solved within 127.461 calls to the MF; the combined method required 76.665 calculation of the MF. That is, the latter worked 1.66 faster than the first.

\section{DISCUSSION}

A typical optimization example is shown in Figure 1. Given: the MF and the boundaries of the segment of uncertainty $[c, d]$. To solve the problem, 5 methods were used: DS (Bisec), GSS (Gold), EDS (Eds), BM (Brent), N3o (N3o).

The lowest performance was shown by the DS, when used to solve the problem, it was required to calculate the minimized function 44 times. The GSS gave 31 calculations, the EDS required 26 calculations, the Brent method -10 , and the proposed Newtonian method gave the best result -8 calculations.

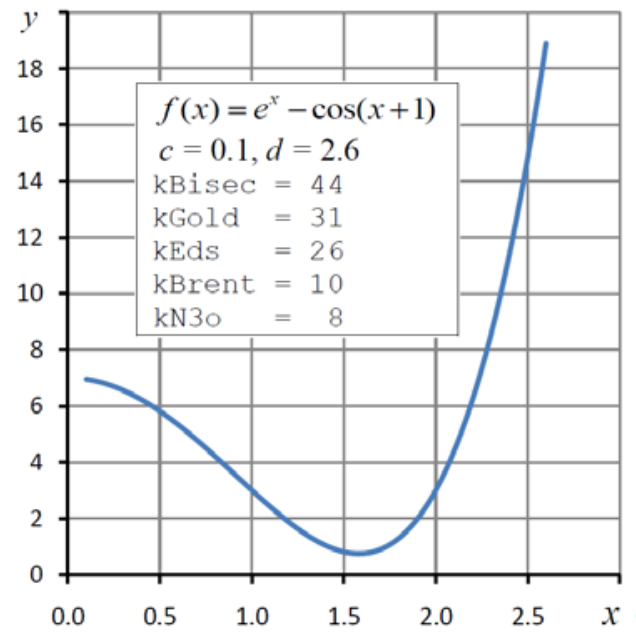

Figure 1 - Extreme function minimization results 
When performing mass calculations on extreme problems for 26 functions, the minimum of which is inside the uncertainty segments, it was found that the Newtonian method is $13 \%$ faster than the Brent method. When solving problems, the Brent method required 63.092 calls to the MF, the Newtonian method - 55.873 times. In 4.830 problems out of 5.131 , the Newton method worked faster $(94.1 \%)$ and only in 301 cases the Brent method worked faster (5.6\%). Thus, the Newtonian method showed the best result in mass calculations.

It was established that the Brent method had advantages over the Newton method only for slowly varying functions on the uncertainty segment. That was the function $f(x)=1000(x-2.8)^{4}-1.6$. For example, on segment $G=[2.2,3.2]$ was obtained $k$ Brent $=25$, $k N 3 o=31$

For any function in the minimization process, the monotonicity identification procedure described in Section 2.2 was applied.

As mentioned, monotonicity identification requires 2 additional function calculations. Therefore, in order not to lose speed, on the one hand, the procedure should be applied only at a high probability that the function is monotonic, and, on the other hand, the speed of the procedure should not be inferior to the Brent method for extreme functions, an example of which is shown in Figure 1.

Conducted above analysis showed that for the used extremal problems BM works approximately three times faster than the GSS. Therefore, the identification of the monotonicity of the function should be included if two conditions are satisfied: the ordinates $k_{m}-2$ of the calculated points must form a monotonic sequence and the condition $k_{m} \geq k_{g} / 3$ must be satisfied.

So for the one shown in Figure 1 example of $k_{g}=31$. Therefore, monotonicity identification should be carried out when $k_{m}=31 / 3-2 \approx 8$ ordinates of the calculated points give a monotonic sequence. Having computed the MF at two more points, we obtain the speed $k_{m}=8+2=$ 10 , which corresponds to the speed of Brent method for extreme MF.

Figure 2 shows an example of a function monotonic on a segment of the uncertainty of a function. Obviously, the Brent method's speed approximately corresponds to that of the GSS. At the same time, the monotonicity identification procedure made it possible to increase the speed by approximately a factor of three, which corresponds to the speed of the Brent method for extreme problems, the analysis of which presented above.

In order to verify the efficiency of the combined method combining Newtonian search with the monotonicity identification procedure, mass calculations were carried out for 26 extremal and two montonic functions for the segments $[c, d]$ with the parameter $\tau=0.33$. In total, this yielded 7.028 problems, of which 2.075 turned out to be problems with monotone functions, the rest of 4.953 were extremal.

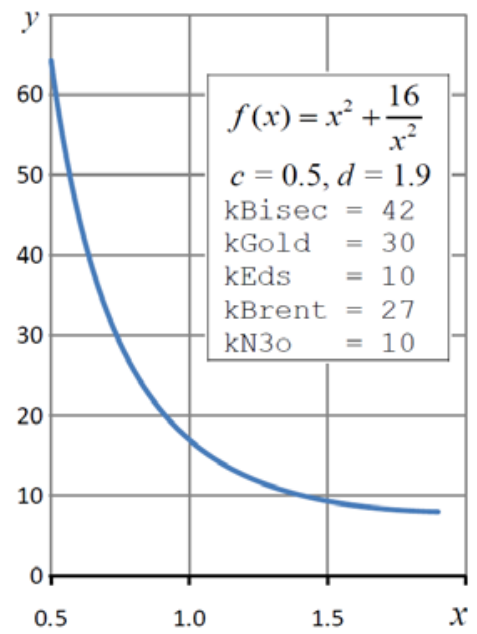

Figure 2 - Monotonic function minimization results

The combined method under consideration turned out to be the best, which solved all the problems having made 74.727 calls to the MF. The Brent method required 113.603 MF calculations. Thus, the combined method completed the problem 1.52 times faster.

Finally, the third kind of optimization problems are problems with fully and partially-constant functions. An example of such a function shown in Figure 3. The function has a flat bottom, any point of which is a solution to the problem.

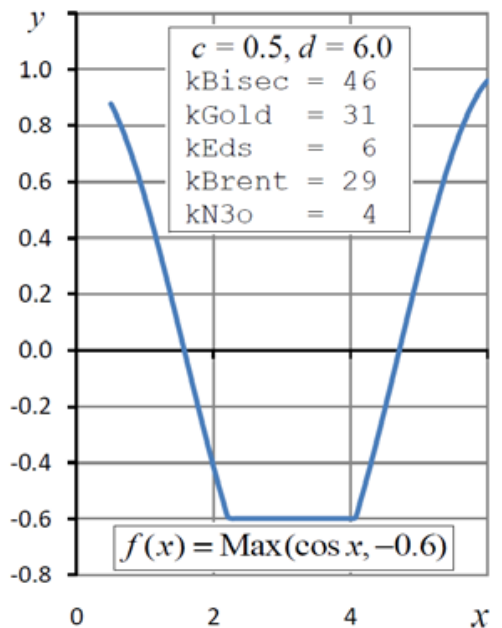

Figure 3 - Partial constant function minimization results

Identifying the minimum point of such a function is quite simple. In this case, no additional calculations are required. As mentioned above, if, during the calculation, sequence $P$ gets three points with the same abscissas, then any of them will be a solution to the problem. For a problem with a function shown in Figure 3, the algorithm finds such a solution in just 4 calls to the function.

It is noteworthy that the EDS for monotonic and partially constant shows the same or close to the Newton method speed of solving problems. This is due to the fact that the described improvements are implemented in this method. 


\section{CONCLUSIONS}

The paper considers and solves the problem of fast minimization of unimodal functions of one variable. A combined third-order Newtonian method of convergence is proposed for minimizing predominantly slowly computed unimodal functions of one variable. A database of problems has been developed, including smooth, monotonic and partially constant functions to test the method and compare its effectiveness with other known methods. The performance of the proposed method is compared with other methods, including the fast Brent method. Analysis of numerous data obtained using computational experiments showed that the proposed method has the highest performance. For smooth extremal functions, the method works $13 \%$ faster than Brent's method, for monotone functions its speed is 3 times higher, for partially constant functions the speed of the method is even higher.

The scientific novelty of the results obtained lies in the fact that for the first time a method for minimizing the minimization of unimodal functions of one variable was proposed, which in general works faster than the wellknown fast methods. The most effective method for minimizing monotonic, constant and partially constant functions. The efficiency of the method is achieved through the use of a computational scheme that guarantees the third order of convergence to the minimum point of the optimized function. The practical value of the results obtained lies in the fact that the proposed method generally works faster than the known methods, which makes it possible to reduce the optimization time for unimodal functions. Prospects for further research are that the developed method can be extended to other functions, for example, to periodic, bimodal and other types of functions.

\section{ACKNOWLEDGEMENTS}

The work was carried out within the framework of the scientific research budget themes "Methods of modeling and optimizing of quality control information systems on the basis of intellectual technologies" at the Department of Standardization, Metrology and Quality Management of the Polytechnic Institute of the Siberian Federal University.

\section{REFERENCES}

1. Sahu D. R., Ansari Q. H., Yao J. C. A unified hybrid iterative method for hierarchical minimization problems, Journal of Computational and Applied Mathematics, 2013, Vol. 253 (1), pp. 208-221. https://doi.org/10.1016/j.cam.2013.04.018.

2. Rao S. S. Engineering optimization: theory and practice, John Wiley \& Sons, 2009. https://doi.org/10.1002/9781119454816.

3. Gill P. E., Murray W., Wright M. H. Practical Optimization, Emerald Group Publishing Limited, 2019. https://doi.org/10.1137/1.9781611975604.

4. Aoki M. Introduction to optimization techniques: Fundamentals and Applications of Nonlinear Programming. London, Macmillan, 1971.

5. Bai Z., Tao M. Rigorous convergence analysis of alternating variable minimization with multiplier methods for quadratic programming problems with equality constraints, BIT
Numerical Mathematics, 2016, 56, pp. 399-422. https://doi.org/10.1007/s10543-015-0563-z.

6. Shor N. Z. Minimization Methods for Non-Differentiable Functions, Springer Berlin Heidelberg, Softcover reprint of the original 1st ed. 1985, 2011. https://doi.org/10.1007/978-3-64282118-9.

7. Himmelblau D. M. Applied Nonlinear Programming. New York, McGraw-Hill, 1972.

8. Hassin R., Reuven H. Asymptotic analysis of dichotomous search with search and travel costs, European Journal of Operational Research, 1992, Vol. 58(1), pp. 78-89. https://doi.org/10.1016/0377-2217(92)90237-4.

9. Glad T., Goldstein A. Optimization of functions whose values are subject to small errors, BIT Numerical Mathematics, 17, 1977, pp. 160-169. https://doi.org/10.1007/bf01932287.

10. Bazaraa M. S., Shetty C. M. Nonlinear Programming, Theory and Algorithms, New York, Wiley, 1979.

11. Chen D., Zhou Y., Song L. Fixed point algorithm based on adapted metric method for convex minimization problem with application to image deblurring, Advances in Computational Mathematics, 2016, 42, pp. 1287-1310. DOI: $10.1007 / \mathrm{s} 10444-$ 016-9462-3.

12. Ruszczynski A. Nonlinear Optimization, Princeton University Press, 2006. https://doi.org/10.1515/9781400841059.

13. Bian W., Chen X., Ye Y. Complexity analysis of interior point algorithms for non-Lipschitz and nonconvex minimization, Mathematical Programming, 2015, 149, pp. 301-327. DOI: 10.1007/s10107-014-0753-5.

14. Cai J., Hanb D., Chen Ch., Chen S. Application of the golden section search algorithm in the nonlinear isoconversional calculations to the determination of the activation energy from nonisothermal kinetic conversion data, Solid State Sciences, 2010, Vol.12 (5), pp. 829-833. DOI: 10.1021/ef7006672.

15. Kodnyanko V. A. Economical dichotomous search for minimizing one-variable functions, Radio Electronics, Computer Science, Control, 2019, No. 3, pp. 34-39. DOI: 10.15588/1607-3274-2019-3-4

16. Weerakoon S., Fernando T. G. I. A variant of Newton's method with accelerated third-order convergence, Applied Mathematics Letters, 2000, Vol. 13, pp. 87-93. DOI: 10.1016/S08939659(00)00100-2

17. Brent R. P. Algorithms for Minimization Without Derivatives, Dover, 2002. DOI: 10.2307/2005713

18. Deng Y., Glimm J., Yu Q., Eisenberg M. Global minimization for problems with multiple local minima, Applied Mathematics Letters, 1993, Vol. 6 (2), pp. 89-90. https://doi.org/10.1016/0893-9659(93)90019-j.

19. Gerald C. F., Wheatley P. O. Applied Numerical Analysis, fifth ed., Addison-Wesley Pub. Co., MA, 1994. https://doi.org/10.2307/2007813.

20. Atkinson K. Intro to Numerical Analysis, 2nd Edition, John Wiley \& Sons, 1989.

21. Guimier A. Modelisation d'algorithmes d'optimisation a strategie aleatoire, Calcolo, 1998, 23, pp. 21-43. https://doi.org/10.1007/bf02576906.

22. Salgueiroda Silva M. A. A novel method for robust minimisation of univariate functions with quadratic convergence, Journal of Computational and Applied Mathematics, 2007, Vol. 200 (1), pp. 168-177. https://doi.org/10.1016/j.cam.2005.12.020.

23. Archetti F. Evaluation of random gradient techniques for unconstrained optimization, Calcolo, 1975, 12, pp. 83-94. https://doi.org/10.1007/bf02576717.

Received 12.04.2021. Accepted 23.05.2021. 


\section{КОМБІНОВАНИЙ НЬЮТОНІВСЬКОЇ МЕТОД ТРЕТЬОГО ПОРЯДКУ ЗБІЖНОСТІ ДЛЯ МІНІМІЗАЦІЇ ФУНКЦІЙ ОДНІЁ̈ ЗМІННОЮ}

Коднянко В. А. - д-р техн. наук, професор кафедри стандартизації, метрології та управління якістю, Політехнічний інститут Сибірського федерального університету, Красноярськ, Росія.

Григор'сва О. А. - канд. техн. наук, доцент кафедри стандартизації, метрології та управління якістю, Політехнічний інститут Сибірського федерального університету, Красноярськ, Росія.

Строк Л. В. - аспірант Сибірського федерального університету, Красноярськ, Росія.

\section{АНОТАЦІя}

Актуальність. У статті розглядається актуальна проблема чисельної оптимізації повільно обчислюваних унімодальних функцій однієї змінної. Проведено аналіз існуючих методів мінімізації першого і другого порядку збіжності, який показав, що ці методи можуть бути використані для швидкого вирішення цих завдань для функцій, значення яких можуть бути отримані без труднощів. Для повільно обчислюваних функцій ці методи дають повільні алгоритми, тому актуальною $\epsilon$ задача розробки швидких методів для мінімізації таких функцій.

Мета. Розробка комбінованого ньютоновского методу третього порядку збіжності для мінімізації переважно повільно обчислюваних унімодальних функцій, а також розробка бази даних, що включає гладкі, монотонні і частково постійні функції, для перевірки методу і порівняння його ефективності з іншими відомими методами.

Метод. Викладається методика і алгоритм вирішення завдання швидкої мінімізації унімодальної функції однієї змінної комбінованим чисельним ньютоновским методом третього порядку збіжності. Метод здатний розпізнавати строго унімодальне, монотонні і постійні функції, а також функції з частковими або повними ділянками плоского мінімуму.

Результати. Наводяться результати порівняння запропонованого методу з іншими методами, в тому числі швидким методом Брента. За допомогою комбінованого ньютоновского методу вирішено 6954 завдання, при цьому метод виявився швидше за інших методів в 95,5\% завдань, метод Брента працював швидше лише в 4,5\% завдань.В цілому аналіз результатів розрахунку показав, що комбінований метод працював в 1,64 рази швидше, ніж метод Брента.

Висновки. Запропоновано комбінований ньютоновский метод третього порядку збіжності для мінімізації переважно повільно обчислюваних унімодальних функцій однієї змінної. Розроблено базу даних завдань, включаючи гладкі, монотонні і частково постійні функції, для перевірки методу і порівняння його ефективності з іншими відомими методами. Показано, що запропонований метод в порівнянні 3 іншими методами, включаючи швидкий метод Брента, має більш високу швидкодію.

КЛЮЧОВІ СЛОВА: унімодальна функція, метод Брента, метод Ньютона, швидкість методу.

УДК 519.67

\section{КОМБИНИРОВАННЫЙ НЬЮТОНОВСКИЙ МЕТОД ТРЕТЬЕГО ПОРЯДКА СХОДИМОСТИ ДЛЯ МИНИМИЗАЦИИ ФУНКЦИЙ ОДНОЙ ПЕРЕМЕННОЙ}

Коднянко В. А. - д-р техн. наук, профессор кафедры стандартизации, метрологии и управления качеством, Политехнический институт Сибирского федерального университета, Красноярск, Россия.

Григорьева О. А. - канд. техн. наук, доцент кафедры стандартизации, метрологии и управления качеством, Политехнический институт Сибирского федерального университета, Красноярск, Россия.

Строк Л. В. - аспирант Сибирского федерального университета, Красноярск, Россия.

\section{АННОтАцИЯ}

Актуальность. В статье рассматривается актуальная проблема численной оптимизации медленно вычисляемых унимодальных функций одной переменной. Проведен анализ существующих методов минимизации первого и второго порядка сходимости, который показал, что эти методы могут быть использованы для быстрого решения этих задач для функций, значения которых могут быть получены без затруднений. Для медленно вычисляемых функций эти методы дают медленные алгоритмы, поэтому актуальной является задача разработки быстрых методов для минимизации таких функций.

Цель. Разработка комбинированного ньютоновского метода третьего порядка сходимости для минимизации преимущественно медленно вычисляемых унимодальных функций, а также разработка базы данных, включающая гладкие, монотонные и частично постоянные функции, для проверки метода и сравнения его эффективности с другими известными методами.

Метод. Излагается методика и алгоритм решения задачи быстрой минимизации унимодальной функции одной переменной комбинированным численным ньютоновским методом третьего порядка сходимости. Метод способен распознавать строго унимодальные, монотонные и постоянные функции, а также функции с частичными или полными участками плоского минимума.

Результаты. Приводятся результаты сравнение предлагаемого метода с другими методами, в том числе быстрым методом Брента. С помощью комбинированного ньютоновского метода решено 6954 задачи, при этом метод оказался быстрее других методов в 95,5\% задач, метод Брента работал быстрее лишь в 4,5\% задач. В целом анализ результатов расчета показал, что комбинированный метод работал в 1,64 раза быстрее, чем метод Брента.

Выводы. Предложен комбинированный ньютоновский метод третьего порядка сходимости для минимизации преимущественно медленно вычисляемых унимодальных функций одной переменной. Разработана база данных задач,

(C) Kodnyanko V. A., Grigorieva O. A., Strok L. V., 2021

DOI 10.15588/1607-3274-2021-2-5 
включая гладкие, монотонные и частично постоянные функции, для проверки метода и сравнения его эффективности с другими известными методами. Показано, что предлагаемый метод по сравнению с другими методами, включая быстрый метод Брента, имеет более высокое быстродействие.

КЛЮЧЕВЫЕ СЛОВА: унимодальная функция, метод Брента, метод Ньютона, скорость метода.

\section{ЛІТЕРАТУРА / ЛИТЕРАТУРА}

1. Sahu D. R. A unified hybrid iterative method for hierarchical minimization problems / D. R. Sahu, Q. H. Ansari, J. C. Yao // Journal of Computational and Applied Mathematics. - 2013. Vol. $\quad 253 \quad$ (1). $\quad$ - $\quad$ P. $\quad 208-221$. https://doi.org/10.1016/j.cam.2013.04.018.

2. Rao S. S. Engineering optimization: theory and practice / S. S. Rao. - Sidney : John Wiley \& Sons, 2009. - 832 p. https://doi.org/10.1002/9781119454816.

3. Gill P. E. Practical Optimization / P. E. Gill, W. Murray, M. H. Wright. - London : Academic Press Limited, 2019. 418 p. https://doi.org/10.1137/1.9781611975604.

4. Aoki M. Introduction to optimization techniques: Fundamentals and Applications of Nonlinear Programming / M. Aoki. London : Macmillan, 1971. - 335 p.

5. Bai Z. Rigorous convergence analysis of alternating variable minimization with multiplier methods for quadratic programming problems with equality constraints / Z . Bai, M. Tao // BIT Numerical Mathematics - 2016. - № 56. P. 399-422. https://doi.org/10.1007/s10543-015-0563-z.

6. Shor N. Z. Minimization Methods for Non-Differentiable Functions / N. Z. Shor. - Berlin : Springer, 1985. - 164 p. https://doi.org/10.1007/978-3-642-82118-9.

7. Himmelblau D. M. Applied Nonlinear Programming / D. M. Himmelblau. - New York: McGraw-Hill, 1972. - 498 p.

8. Hassin R. Asymptotic analysis of dichotomous search with search and travel costs / R. Hassin, H. Reuven // European Journal of Operational Research. - 1992. - Vol. 58. - P. 78-89. https://doi.org/10.1016/0377-2217(92)90237-4

9. Glad T. Optimization of functions whose values are subject to small errors / T. Glad, A. Goldstein // BIT Numerical Mathematics - 1977. - № 17. - P. 160-169. https://oi.org/10.1007/bf01932287.

10. Bazaraa M. S. Nonlinear Programming, Theory and Algorithms / M. S. Bazaraa, C. M. Shetty. - New York : Wiley, 1979. $872 \mathrm{p}$.

11. Chen D. Fixed point algorithm based on adapted metric method for convex minimization problem with application to image deblurring / D. Chen, Y. Zhou, L. Song // Advances in Computational Mathematics - 2016. - № 42. - P. 1287-1310.

12. Ruszczynski A. Nonlinear Optimization / A. Ruszczynski New Jersey : Princeton University Press, 2006. - 464 p. https://doi.org/10.1515/9781400841059.
13. Bian W. Complexity analysis of interior point algorithms for non-Lipschitz and nonconvex minimization / W. Bian, X. Chen, Y. Ye // Mathematical Programming - 2015. № 149. - P. 301-327.

14. Application of the golden section search algorithm in the nonlinear isoconversional calculations to the determination of the activation energy from nonisothermal kinetic conversion data / [J. Cai, D. Hanb, Ch. Chen, S. Chen] // Solid State Sciences. - 2010. - Vol. 12 (5). - P. 829-833.

15. Kodnyanko V. A. Economical dichotomous search for minimizing one-variable functions, / V. A. Kodnyanko // Radio Electronics, Computer Science, Control. - 2019. - № 3. P. 34-39.

16. Weerakoon S. A variant of Newton's method with accelerated third-order convergence / S. Weerakoon, T. G. I. Fernando //, Applied Mathematics Letters. - 2000. - Vol. 13. - P. 87-93.

17. Brent R. P. Algorithms for Minimization Without Derivatives / R. P. Brent. - New York : Dover Publications, 2002. - 206 p.

18. Global minimization for problems with multiple local minima / [Y. Deng, J. Glimm, Q. Yu, M. Eisenberg] // Applied Mathematics Letters. - 1993. - Vol. 6 (2). - P. 89-90. https://doi.org/10.1016/0893-9659(93)90019-j.

19. Gerald C. F. Applied Numerical Analysis, fifth ed. / C. F. Gerald, P. O. Wheatley - Boston : Addison Wesley Publishing Company, $1994 . \quad-\quad 748$ p. https://doi.org/10.2307/2007813.

20. Atkinson K. Intro to Numerical Analysis, 2nd Edition / K. Atkinson. - Sidney : John Wiley \& Sons. 1989. - 712 p.

21. Guimier A. Modelisation d'algorithmes d'optimisation a strategie aleatoire / A. Guimier // Calcolo. - 1986. - № 23. P. 21-43. https://doi.org/10.1007/bf02576906.

22. Salgueiroda Silva M. A. A novel method for robust minimisation of univariate functions with quadratic convergence / M. A. Salgueiroda Silva // Journal of Computational and Applied Mathematics. - 2007. $\begin{array}{llllll}\text { Vol. } & 200 & \text { (1). } & \text { - } & \text { P. } & \text { 168-177. }\end{array}$ https://doi.org/10.1016/j.cam.2005.12.020.

23. Archetti F. Evaluation of random gradient techniques for unconstrained optimization / F. Archetti // Calcolo. - 1975. № 12. - P. 83-94. https://doi.org/10.1007/bf02576717. 